Research Product 98-31

\title{
Task Analyses of Military Intelligence Critical Combat Functions
}

\author{
Terry P. Bartkoski and Kent E. Harrison \\ PRC, Inc. \\ Dorothy L. Finley \\ U.S. Army Research Institute
}

\section{Armored Forces Research Unit \\ Barbara A. Black, Chief}

U.S. Army Research Institute for the Behavioral and Social Sciences 5001 Eisenhower Avenue, Alexandria, Virginia 22333-5600

Office, Deputy Chief of Staff for Personnel

Department of the Army

January 1998 